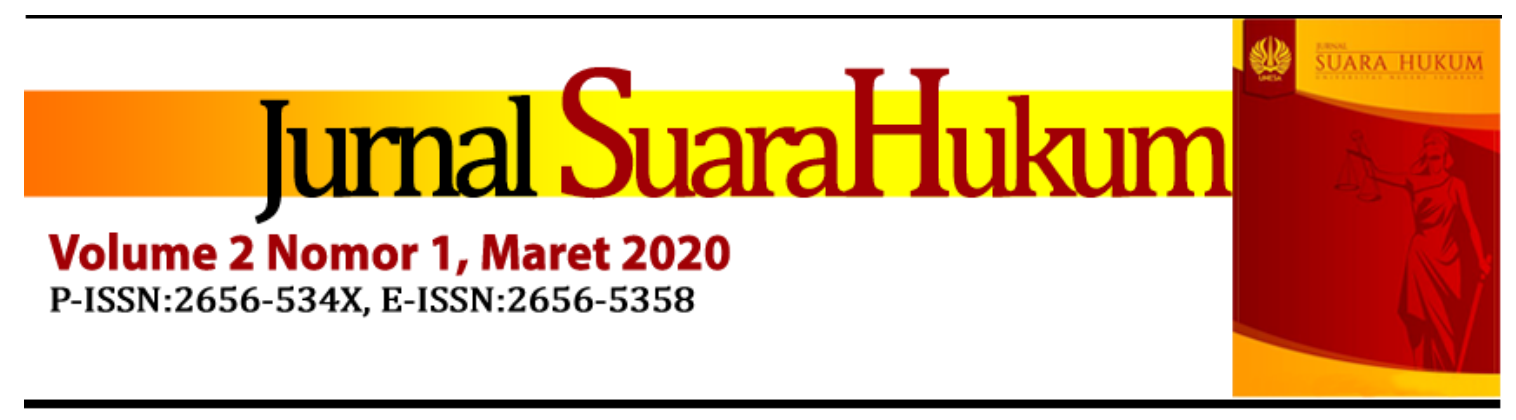

\title{
Keabsahan Putusan Pengadilan yang Belum Inkracht sebagai Novum dalam Pengajuan Peninjauan Kembali
}

\author{
Yoefanca Halim ${ }^{1}$ dan Hardy Salim ${ }^{2}$ \\ ${ }^{1}$ Fakultas Hukum Universitas Tarumanagara \\ yoefancahalim.9a35@gmail.com \\ 2Fakultas Hukum Universitas Tarumanagara \\ hardys197@gmail.com
}

\begin{abstract}
A judicial institution is called good, not only if the process is honest, clean, and impartial. But in addition there are more criteria that must be met, namely principles that are open, corrective, and recordive. In this criterion, one side that deserves the attention of judicial management is the existence of a good legal remedial system as part of the principle of fairness and trial independence which are universally recognized principles. The broadest opportunity to submit corrections and recordings of decisions that have permanent legal force (inkracht) deemed unfair by justice seekers can be done through a Judicial Review. However, the Judicial Review is very limitative, one of them with the requirement for novum. But the regulation of conditions can be said to be a condition as a novum not strictly regulated. Seeing this raises a problem about, "What is the validity of a court decision that has not been inkracht as a novum in submitting a review?". The method used in this study is a normative or juridical legal research method.
\end{abstract}

Keywords: Legitimacy, Court Decision, Judicial Review, Novum.

\section{Pendahuluan}

Pemikiran atau konsep manusia tentang Negara Hukum lahir dan berkembang seiring dengan perkembangan sejarah manusia. Plato dan Aristoteles mengintrodusir Negara Hukum adalah negara yang diperintah oleh negara yang adil. Dalam filsafatnya, keduanya menyinggung angan-angan (citacita) manusia yang berkorespondensi dengan dunia yang mutlak yang disebut: ${ }^{1}$

1) Moh. Kusnardi dan Bintan Saragih, Ilmu Negara, (Jakarta: Gaya Media, 2000), hal. 131. 
1. Cita-cita untuk mengejar kebenaran (idée der warhead);

2. Cita-cita untuk mengejar kesusilaan (idée der zodelijkheid);

3. Cita-cita manusia untuk mengejar keindahan (idée der schonheid); dan

4. Cita-cita untuk mengejar keadilan (idée der gorechtigheid).

Aristoteles merumuskan negara hukum adalah negara yang berdiri di atas hukum yang menjamin keadilan kepada warga negaranya. Menurut Aristoteles, keadilan dapat berupa komunikatif (menjalankan keadilan) dan distribusi (memberikan keadilan). ${ }^{2}$

Negara Indonesia adalah negara yang berdasarkan atas hukum (rechtsstaat). Dasar pijakan bahwa negara Indonesia adalah negara hukum tertuang pada Pasal 1 ayat (3) Undang-Undang Dasar Negara Republik Indonesia Tahun 1945 (yang selanjutnya disebut dengan UUD NRI 1945), yang menyebutkan bahwa "negara Indonesia adalah negara hukum." Indonesia menerima hukum sebagai ideologi untuk menciptakan ketertiban, keamanan, keadilan serta kesejahteraan bagi warga negaranya. Konsekuensinya adalah bahwa hukum mengikat setiap tindakan yang dilakukan oleh warga negara Indonesia. Negara Indonesia menjunjung tinggi Hak Asasi Manusia serta menjamin warga negara bersamaan kedudukannya di dalam hukum dan pemerintahan dan wajib menjunjung hukum dan pemerintahan itu dengan tidak ada kecualinya. Oleh karena itu, penyusunan dan penerapan tata hukum di Indonesia sejak berlakunya UUD NRI 1945 harus dilandasi dan dijiwai oleh Pancasila termasuk dalam menciptakan peraturan-peraturannya, salah satunya adalah Undang-Undang Nomor 8 Tahun 1981 tentang Hukum Acara Pidana (yang selanjutnya disebut dengan KUHAP). ${ }^{3}$

Berlakunya KUHAP telah menimbulkan perubahan mendasar baik secara konsepsional maupun secara implemental terhadap tata cara penyelesaian perkara pidana Indonesia. KUHAP merupakan peraturan yang mengatur, menyelenggarakan, dan mempertahankan eksistensi ketentuan hukum pidana

2) Azhary, Negara Hukum Indonesia (Analisis Yuridis Normatif tentang Unsur-Unsurnya), (Universitas Indonesia: UI Press, 1995), hal. 21.

3) Parman Soeparman, Pengaturan Hak Mengajukan Upaya Hukum Peninjauan Kembali dalam Perkara Pidana Bagi Korban Kejahatan, (Bandung: Regika Aditama, 2009), hal. 8-9. 
guna mencari, menemukan, dan mendapatkan kebenaran materiil atau yang sesungguhnya. ${ }^{4}$ Sifat hukum acara pidana itu haruslah memberikan kepastian prosedur dan rasa keadilan baik dari anasir yang dituntut maupun dari kepentingan masyarakat itu sendiri, karena keadilan adalah hak semua orang dan tidak dikecualikan dari hal-hal apa pun sebagai bagian dari hak dasar yang tidak boleh diganggu karena bertujuan untuk menciptakan suansana damai di kalangan masyarakat yang dapat diperoleh lewat panggung peradilan. ${ }^{5}$

Prinsip universal mengakui bahwa semua orang sama dan mempuyai hak sama di hadapan hukum serta berhak atas perlindungan hukum tanpa perlakuan atau sikap diskriminasi apapun. Setiap orang mempunyai hak atas peradilan yang efektif jika ada pelanggaran terhadap hak-hak yang dijamin oleh ketentuan hukum positif. Para pihak yang mengalami proses peradilan, termasuk upaya peninjauan kembali, diberikan kesempatan seluas-luasnya untuk mengajukan koreksi dan rekoreksi terhadap putusan yang telah berkekuatan hukum tetap (inkracht) yang dipandang tidak adil oleh pencari keadilan.

Sebagai negara hukum, Indonesia sudah sejak lama konsisten dalam mengarahkan sistem hukum acara peradilannya ke arah demikian. KUHAP mengatur pembagian upaya hukum antar lain upaya hukum biasa yang meliputi banding dan kasasi, dan upaya hukum luar biasa yang meliputi kasasi demi kepentingan hukum dan peninjauan kembali. Khusus mengenai peninjauan kembali telah lama diterapkan di Indonesia dan telah mengalami perkembangan yang cukup pesat mengingat bahwa hakim sebagai manusia biasa yang tidak luput dari kesalahan dan kekurangan.

Peninjauan kembali semata-mata ditujukan bagi kepentingan terpidana saja, bukan kepentingan negara atau korban. Terkandung dasar filosofis mengapa hak untuk mengajukan peninjauan kembali semata-mata

4) Lilik Mulyadi, Hukum Acara Pidana Suatu Tinjauan Khusus Terhadap Surat Dakwaan, Eksepsi dan Putusan Pengadilan, (Bandung: Citra Aditya Bakti, 1996), hal. 4.

5) Soerjono Soekanto dan Purnadi Purbacaraka, Perihal Kaidah Hukum, (Bandung: Alumni, 1978), hal. 19. 
diperuntukkan bagi terpidana. Bahwa substansi upaya hukum peninjauan kembali berpijak pada dasar, bahwa negara telah salah memidana (miscarriage of justice) penduduk yang tidak berdosa yang tidak dapat diperbaiki lagi dengan upaya hukum biasa. ${ }^{6}$

Seperti halnya upaya hukum lainnya, pada prinsipnya peninjauan kembali tidak diperkenankan untuk putusan bebas dan lepas dari segala tuntutan hukum. Selain dari dua putusan tersebut, peninjauan kembali dapat diajukan khusus untuk yang telah berkekuatan hukum tetap. ${ }^{7}$ Para pihak yang dapat mengajukan peninjauan kembali adalah terpidana atau ahli warisnya. Penuntut umum tidak diperkenankan untuk melakukan peninjauan kembali. ${ }^{8}$

Peninjauan kembali sebagai upaya hukum luar biasa tidak mudah untuk begitu saja dimasukkan sebagai aturan hukum positif, sebab sudah ada aturan hukum mendasar yang berlaku universal tentang ne bis in idem (tidak boleh dua kali mengadili perkara yang sama). Ketentuan ini terdapat di dalam hukum pidana materiil (Pasal 76 Kitab Undang-Undang Hukum Pidana). Salah satu inti dari lalu lintas argumentasi tentang perdebatan aturan peninjauan kembali nyata ada dalam tabrakan aturan itu dengan ne bis in idem sebab jika satu perkara yang sama masih bisa diperiksa ulang dan lagi pula sudah inkracht maka jelas tidak sesuai dengan dasar dan tujuan utama hukum pidana. ${ }^{9}$

Penggunaan peninjauan kembali diatur sebagai upaya hukum luar biasa menjadi sangat limitative. Hal itu dikarenakan telah ditentukannya alasan atau syarat untuk mengajukan peninjauan kembali atas suatu putusan perkara pidana yang telah memeroleh kekuatan hukum tetap (inkracht) sebagaimana diatur dalam Pasal 263 KUHAP. Pasal 263 ayat (1) KUHAP mengatur mengenai syaratsyarat pokok dalam mengajukan peninjauan kembali. Jika prasyarat dalam Pasal

\footnotetext{
${ }^{6}$ Adami Chazawi, Lembaga Peninjauan Kembali (PK) Perkara Pidana: Penegakan Hukum dalam Penyimpangan Praktik \& Peradilan Sesat, (Jakarta: Sinar Grafika, 2010), hal. 8.

7 Tolib Effendi, Dasar-Dasar Hukum Acara Pidana: Perkembangan dan Pembaharuannya di Indonesia, (Malang: Setara Press, 2014), hal. 196.

${ }^{8}$ Ibid.

9 Nikolas Simanjuntak, Acara Pidana Indonesia dalam Sirkus Hukum, (Bogor: Ghalia Indonesia, 2009), hal. 308.
} 
263 ayat (1) KUHAP sudah dipenuhi, namun ayat (2) masih bersifat limitative, artinya salah satu persyaratan pada ayat (2) sudah terpenuhi sehingga berdasarkan ayat (3) peninjauan kembali dapat dimohonkan kepada Mahkamah Agung. ${ }^{10}$

Salah satu syarat dalam mengajukan peninjauan kembali adalah apabila terdapat keadaan baru yang menimbulkan dugaan kuat, bahwa jika keadaan itu sudah diketahui pada waktu sidang masih berlangsung, hasilnya akan berupa putusan bebas atau putusan tidak dapat diterima atau terhadap perkara itu diterapkan ketentuan pidana yang lebih ringan. ${ }^{11}$ "Keadaan baru" ini biasa dikenal dengan istilah "novum", yaitu suatu hal baru yang timbul kemudian sesudah adanya putusan pengadilan yang telah memperoleh kekuatan hukum tetap yang sebelumnya tidak pernah menjadi pembicaraan atau tidak dipersoalkan atau menjadi pembuktian di dalam pemeriksaan pengadilan pada semua tingkat pengadilan.

Pengajuan peninjauan kembali dalam beberapa kasus yang ada di Indonesia dilakukan apabila terdapat suatu novum atau kekhilafan hakim yang menjadi syarat lain berdasarkan Pasal 263 ayat (2) KUHAP. Apabila tidak terdapat novum atau tidak terpenuhinya syarat dalam Pasal 263 KUHAP, maka pengajuan peninjauan kembali tidak dapat dikabulkan oleh Mahkamah Agung, tidak terkecuali siapapun pihak yang mengajukannya. Sedangkan apabila terpenuhi syarat-syarat yang diatur dalam Pasal 263 KUHAP, maka Mahkamah Agung harus mempertimbangkan kebenaran dari putusan yang diajukan upaya hukum luar biasa tersebut. Namun pengaturan mengenai syarat-syarat dapat dikatakan suatu keadaan sebagai novum tidak diatur secara tegas, sehingga muncul perdebatan-perdebatan terkait bentuk dari novum ini. Sebagai salah satu contoh kasus adalah pengajuan peninjauan kembali oleh terpidana perkara

\footnotetext{
${ }^{10}$ Abdi Sofyan dan Abd. Asis, Hukum Acara Pidana: Suatu Pengantar, (Jakarta: Kencana, 2014), hal. 293.

${ }^{11}$ Kitab Undang-Undang Hukum Acara Pidana, Pasal 263 ayat (2).
} 
penistaan agama Basuki Tjahaja Purnama terhadap putusan vonis untuk dirinya yaitu Putusan Nomor 1537/Pid.B/2016/PN Jkt.Utr.

Tim kuasa hukum dari Basuki Tjahaja Purnama atau yang biasa dikenal dengan panggilan "Ahok", memakai putusan terpidana pelanggaran UndangUndang Nomor 11 Tahun 2008 tentang Informasi dan Transaksi Elektronik, yakni Buni Yani, sebagai salah satu dasar pengajuan memori peninjauan kembali. Sementara putusan perkara itu belum berkekuatan hukum tetap (inkracht). Sebab, Buni Yani masih mengajukan banding atas vonis Majelis Hakim Pengadilan Negeri Bandung tersebut.

Muncul perbedaan pendapat dari para pakar hukum dalam menanggapi hal tersebut. Terdapat pihak yang mengatakan bahwa putusan yang belum inkracht dapat dijadikan novum dalam mengajukan peninjauan kembali, seperti yang dikemukakan oleh Abdullah, seorang Kepala Biro Hukum dan Humas Mahkamah Agung. Sedangkan pihak lainnya mengatakan bahwa putusan yang belum inkracht tidak dapat dijadikan novum dalam mengajukan peninjauan kembali, seperti yang dikemukakan oleh Agustinus Pohan, seorang ahli hukum pidana Universitas Parahyangan. ${ }^{12}$ Penulis menilai belum terdapat kajian atau penelitian yang membahas persoalan ini sebelumnya. Oleh karena itu penulis tertarik membahasnya untuk memahami lebih dalam mengenai keabsahan putusan pengadilan yang belum inkracht sebagai novum dalam pengajuan peninjauan kembali.

\section{Metode Penelitian}

Penelitian ini merupakan penelitian hukum normatif, yang menggunakan bahan-bahan kepustakaan sebagai sumber data penelitian, ${ }^{13}$ meliputi bahan hukum primer, sekunder dan tersier. ${ }^{14}$ Bahan hukum primer yang digunakan

12 "Putusan Buni Yani Belum Inkrah, Dasar PK Ahok Dipertanyakan", https://m.cnnindonesia.com/nasional/20180221084125-12-277624/putusan-buni-yani-belum-inkrahdasar-pk-ahok-dipertanyakan, diakses tanggal 24 September 2019.

${ }^{13}$ Bambang Sunggono, Metode Penelitian Hukum, (Jakarta: PT. Raja Grafindo Persada, 2007), hal. 133.

${ }^{14}$ Soerjono Soekanto, Pengantar Penelitian Hukum, (Jakarta: UI-Press, 1986), hal. 52. 
terdiri atas Kitab Undang-Undang Hukum Pidana, Undang-Undang Nomor 8 Tahun 1981 tentang Kitab Undang-Undang Hukum Acara Pidana, serta peraturan perundang-undangan terkait lainnya. Adapun bahan hukum sekunder meliputi buku teks, jurnal hukum, dan eksaminasi putusan pengadilan. ${ }^{15}$ Penelitian ini bersifat deskriptif kualitatif, yang mendeskripsikan dan menyajikan data mengenai objek penelitian. ${ }^{16}$ Analisis data dilakukan dengan mengkaji atau menelaah bahan hukum dengan merujuk pada teori sebagai pisau analisa untuk menghasilkan kesimpulan dari hasil penelitian. ${ }^{17}$

\section{Hasil Penelitian dan Pembahasan}

\section{Teori Tiga Dasar Nilai Hukum}

Gustav Radbruch adalah seorang filosof hukum dan seorang legal scholar dari Jerman yang terkemuka. Gustav mengajarkan konsep tiga ide unsur dasar hukum. Ketiga konsep dasar tersebut dikemukakan pada era Perang Dunia II. Tujuan hukum versi Gustav tersebut oleh berbagai pakar diidentikkan juga sebagai tujuan hukum. Adapun tiga tujuan hukum tersebut adalah keadilan, kepastian, dan kemanfaatan.

\section{a. Keadilan}

Keadilan memiliki sifat normatif sekaligus konstitutif bagi hukum. Keadilan menjadi landasan moral hukum dan sekaligus tolak ukur sistem hukum positif dan tanpa keadilan, sebuah aturan tidak pantas menjadi hukum. Sebagaimana dikemukakan Muchsin, bahwa keadilan merupakan salah satu tujuan dari hukum selain dari kepastian hukum itu sendiri dan juga kemanfaatan hukum.

Makna keadilan memang masih menuai perdebatan. Meski demikian, keadilan terkait dengan pendistribusian yang merata antara

\footnotetext{
${ }^{15}$ Peter Mahmud Marzuki, Penelitian Hukum, (Jakarta: Kencana, 2013), hal. 181.

16 Tunjung Herning Sitabuana (b), "Penyelesaian Masalah Diskriminasi Terhadap Etnis Cina (Studi Tentang Perkembangan Politik Hukum di Bidang Kewarganegaraan Republik Indonesia)", (Ringkasan Disertasi Doktor, Universitas Diponegoro, 2011), hal. 86.

${ }^{17}$ Mukti Fajar ND dan Yulianto Achmad, Dualisme Penelitian Hukum Normatif dan Empiris, Cetakan Ke- 1, (Yogyakarta: Pustaka Belajar, 2010), hal. 183.
} 
hak dan kewajiban. Sentral dan dominannya kedudukan dan peranan dari nilai keadilan bagi hukum, sehingga Gustav Radbruch menyatakan" rechct ist wille zur gerechtigkeit" (hukum adalah kehendak demi untuk keadilan). ${ }^{18}$ Sedangkan Soejono K.S mendefinisikan keadilan adalah keseimbangan batiniah dan lahiriah yang memberikan kemungkinan dan perlindungan atas kehadiran dan perkembangan kebenaran yang beriklim toleransi dan kebebasan. ${ }^{19}$ Menurut Aristoteles tedapat 5 jenis keadilan, yaitu: ${ }^{20}$

1. Keadilan Komutatif adalah perlakuan terhadap seseorang dengan tidak melihat jasa-jasa yang telah diberikannya.

2. Keadilan Distributif adalah perlakuan terhadap seseorang sesuai dengan jasa-jasa yang telah diberikannya.

3. Keadilan Kodrat Alam adalah memberi sesuatu sesuai dengan yang diberikan oleh orang lain kepada kita.

4. Keadilan Konvensional adalah kondisi jika seorang warga negara telah menaati segala peraturan perundang-undangan yang telah dikeluarkan.

5. Keadilan Perbaikan adalah perbuatan adil menurut perbaikan adalah jika seseorang telah berusaha memulihkan nama baik orang lain yang telah tercemar.

\section{b. Kepastian Hukum}

Kepastian hukum itu adalah kepastian undang-undang atau peraturan, segala macam cara, metode dan lain sebagainya harus berdasarkan undang-undang atau peraturan. Didalam kepastian hukum terdapat hukum positif dan hukum tertulis. Hukum tertulis disusun oleh lembaga yang berwenang, mempunyai sanksi yang tegas, sah dengan sendirinya ditandai dengan diumumkannya di lembaga negara. ${ }^{21}$

Kepastian hukum merupakan pertanyaan yang hanya bisa dijawab secara normatif, bukan sosiologis. Kepastian hukum secara normatif adalah ketika suatu peraturan dibuat dan diundangkan secara pasti karena mengatur secara jelas dan logis.

Jelas dalam artian tidak menimbulkan keragu-raguan (multi-tafsir) dan logis dalam artian ia menjadi suatu sistem norma dengan norma lain sehingga tidak berbenturan atau menimbulkan konflik norma. Konflik

\footnotetext{
${ }^{18}$ Satjipto Rahardjo, Ilmu Hukum, (Bandung: Citra Aditya Bakti, 2012), hal. 10.

${ }^{19}$ Ibid.

${ }^{20}$ Abid Zamzami, "Keadilan Di Jalan Raya", Jurnal Yurispruden Vol. 1 No. 2, Januari 2018, hal. 23.

${ }^{21}$ Satjipto Rahardjo, Op.Cit., hal. 17.
} 
norma yang ditimbulkan dari ketidakpastian aturan dapat berbentuk kontestasi norma, reduksi norma atau distorsi norma.

Pemikiran mainstream beranggapan bahwa kepastian hukum merupakan keadaan dimana perilaku manusia, baik individu, kelompok, maupun organisasi, terikat dan berada dalam koridor yang sudah digariskan oleh aturan hukum. Secara etis, pandangan seperti ini lahir dari kekhawatiran yang dahulu kala pernah dilontarkan oleh Thomas Hobbes bahwa manusia adalah serigala bagi manusia lainnya (homo homini lupus). Manusia adalah makhluk yang beringas yang merupakan suatu ancaman. Untuk itu, hukum lahir sebagai suatu pedoman untuk menghindari jatuhnya korban.

Kemudian muncul pengaruh pemikiran Francis Bacon di Eropa terhadap hukum pada abad XIX nampak dalam pendekatan law and order (hukum dan ketertiban). ${ }^{22}$ Penekanan pada asas kepastian hukum lebih bernuansa pada terciptanya keteraturan dan ketertiban dalam masyarakat. ${ }^{23}$ Ketertiban adalah tujuan pokok dan pertama dari segala hukum. Kebutuhan terhadap ketertiban ini, syarat pokok (fundamental) bagi adanya suatu masyarakat manusia yang teratur. Lepas dari segala kerinduan terhadap hal-hal lain yang juga menjadi tujuan dari hukum, merupakan suatu fakta objektif yang berlaku bagi segala masyarakat manusia dalam segala bentuknya. ${ }^{24}$

\section{c. Kemanfaatan}

Bekerjanya hukum di masyarakat efektif atau tidak. Dalam nilai kemanfaatan, hukum berfungsi sebagai alat untuk memotret fenomena

\footnotetext{
${ }^{22}$ Georger Zwanzerberger, International Law and Order, (London: Steven \& Sons Ltd, 1971), hal. 115.

${ }^{23}$ Ahmad Rifa'i, Penemuan Hukum Oleh Hakim Dalam Perspektif Hukum Progresif, (Jakarta: Sinar Grafika, 2011), hal. 135.

${ }^{24}$ Mochtar Kusumaatmadja, Konsep-Konsep Hukum Dalam Pembangunan, (Bandung: Alumni, 2006), hal. 3 .
} 
masyarakat atau realitasosial. Dapat memberi manfaat atau berdaya guna (utility) bagi masyarakat. ${ }^{25}$

Penganut aliran utilitas menganggap bahwa tujuan hukum sematamata untuk memberikan kemanfaatan atau kebahagiaan yang sebesarbesarnya bagi sebanyak- banyaknya warga masyarakat. Penanganannya didasarkan pada filsafat sosial, bahwa setiap warga masyarakat mencari kebahagiaan, dan hukum merupakan salah satu alatnya. Salah seorang tokoh aliran utilitas yang paling radikal adalah Jeremy Bentham (17481832) yakni seorang filsuf, ekonom, yuris, dan reformer hukum, yang memiliki kemampuan untuk memformulasikan prinsip kegunaan/kemanfaatan (utilitas) menjadi doktrin etika, yang dikenal sebagai utilitarianism atau madzhab utilitis.

Prinsip utility tersebut dikemukakan oleh Bentham dalam karya monumentalnya Introduction to the Principles of Morals and Legislation (1789). ${ }^{26}$ Bentham mendefinisikannya sebagai sifat segala benda tersebut cenderung menghasilkan kesenangan, kebaikan, atau kebahagiaan, atau untuk mencegah terjadinya kerusakan, penderitaan, atau kejahatan, serta ketidakbahagiaan pada pihak yang kepentingannya dipertimbangkan. Aliran utilitas menganggap bahwa pada prinsipnya tujuan hukum itu hanyalah untuk menciptakan kemanfaatan atau kebahagiaan masyarakat. Aliran utilitas memasukkan ajaran moral praktis yang menurut penganutnya bertujuan untuk memberikan kemanfaatan atau kebahagiaan yang sebesar-besarnya bagi sebanyak mungkin warga masyarakat. Bentham berpendapat, bahwa negara dan hukum sematamata ada hanya untuk manfaat sejati, yaitu kebahagiaan mayoritas rakyat.

Akan tetapi, konsep utilitas pun mendapatkan ktitikan tajam seperti halnya yang dialami oleh nilai pertama di atas, sehingga dengan adanya

\footnotetext{
${ }^{25}$ Georger Zwanzerberger, Op.Cit., hlal. 22.

${ }^{26}$ Jeremy Bentham, An Introduction to The Principles of Morals and Legislation. (London: Batoche Books Kichener, 1789), hal. 103.
} 
kritik-kritik terhadap prinsip kemanfaatan hukum tersebut, maka John Rawls, mengembangkan sebuah teori baru yang menghindari banyak masalah yang tidak terjawab oleh utilitarianism. Teori kritikan terhadap utilitas dinamakan teori Rawls atau justice as fairness (keadilan sebagai kejujuran). ${ }^{27}$

\section{Keabsahan Putusan Pengadilan Yang Belum Inkracht Sebagai Novum}

Upaya hukum peninjauan kembali (Herziening) adalah upaya hukum luar biasa yang dilakukan dalam rangka pencapaian rasa keadilan. Peninjauan kembali diatur dalam Pasal 263 ayat (1) KUHAP yang berbunyi, “terhadap putusan pengadilan yang telah mempunyai kekuatan hukum tetap (inkracht), kecuali putusan bebas atau lepas dari segala tuntutan hukum, terpidana atau ahli warisnya dapat mengajukan permintaan Peninjauan Kembali kepada Mahkamah Agung." Pasal 263 ayat (1) KUHAP tersebut poin pengaturannya adalah sebagai berikut:

a. permintaaan peninjauan kembali hanya dapat diajukan terhadap putusan pemidanaan saja;

b. permintaan peninjauan kembali hanya dapat diajukan terhadap putusan yang telah berkekuatan hukum tetap (inkracht); dan

c. permintaan peninjauan kembali dapat diajukan hanya oleh terpidana atau ahli warisnya saja.

Demikian pula syarat-syarat lainnya sebagaimana ditentukan menurut Pasal 263 ayat (2) KUHAP, yaitu:28

a. Apabila terdapat keadaan baru (novum) yang menimbulkan dugaan kuat, bahwa jika keadaan itu sudah diketahui pada waktu sidang masih berlangsung, hasilnya akan berupa putusan bebas (vrijspraak) atau putusan lepas dari segala tuntutan hukum (ontslag van alie rechtsvolging)

\footnotetext{
${ }^{27}$ Rawls, John, A Theory of Justice, Teori Keadilan. Diterjemahkan oleh Uzair Fauzan dan Heru Prasetyo, (Yogyakarta: Pustaka Pelajar, 2006), hal. 10.

${ }^{28}$ Abdi Sofyan dan Abd. Asis, Hukum Acara Pidana..., Op. Cit., hal. 292.
} 
atau tuntutan penuntut umum tidak dapat diterima (niet ontvoankelijk verklaring) atau terhadap perkara itu diterapkan ketentuan pidana yang lebih ringan;

b. Apabila dalam pelbagai putusan terdapat pernyataan bahwa sesuatu telah terbukti, akan tetapi hal atau keadaan sebagai dasar dan alasan putusan yang dinyatakan telah terbukti itu, ternyata telah bertentangan satu dengan yang lain;

c. Apabila putusan itu dengan jelas memperlihatkan suatu kekhilafan hakim atau suatu kekeliruan yang nyata.

Pasal 263 ayat (3) KUHAP juga menentukan syarat pengajuan peninjauan kembali, yaitu: “Terhadap suatu putusan pengadilan yang telah memperoleh kekuatan hukum tetap dapat diajukan permintaan Peninjauan Kembali apabila dalam putusan itu suatu perbuatan yang didakwakan telah dinyatakan terbukti akan tetapi tidak diikuti oleh suatu pemidanaan."

Novum berasal dari bahasa latin yang mempunyai istilah lengkap noviter perventa, yang berarti "newly discovered facts, which are usually allowed to be introduced in a case even after the pleadings are closed". ${ }^{29}$ Sebelum KUHAP diberlakukan, penjelasan atas Pasal 15 Undang-Undang Nomor 19 Tahun 1964 tentang Ketentuan-ketentuan Pokok Kekuasaan Kehakiman telah menyinggung perihal novum yang disebut dengan istilah nova. Pengertian nova sama dengan yang saat ini disebut novum, yaitu "fakta-fakta atau keadaan-keadaan baru, yang pada waktu dilakukan peradilan yang dahulu, tidak tampak atau memperoleh perhatian."

Hakim terikat pada ketentuan minimum pembuktian dalam hal menjatuhkan pidana, sebagaimana yang dinyatakan oleh majelis hakim di dalam putusan Mahkamah Agung Nomor 109/PK/Pid/2007 dengan mantan terdakwa Pollycarpus. Majelis hakim dalam pertimbangannya berpendapat: ${ }^{30}$ 1999).

${ }^{29}$ Bryan A. Garner, ed., Black’s Law Dictionary, 7th ed., (United States of America: West Group,

${ }^{30}$ Mahkamah Agung Republik Indonesia (a), Putusan Mahkamah Agung Nomor 109/PK/Pid/2007 Tertanggal 25 Januari 2008, hal. 42. 
“... adalah merupakan alat bukti yang sah, karena keterangan telah sesuai dengan Pasal 185 dan Pasal 186 KUHAP, yang merupakan keadaan baru sebagaimana dimaksud dalam Pasal 263 ayat (2) huruf a KUHAP, yang dapat menjadi bahan dalam membentuk alat bukti petunjuk."

Menurut D. Simons, sebagaimana yang dikutip dari bukunya P.A.F. Lamintang, syarat pokok untuk melakukan penafsiran terhadap suatu undangundang adalah bahwa undang-undang itu harus ditafsirkan berdasarkan undang-undang itu sendiri. Dia menguraikan bahwa untuk menafsirkan undang-undang itu, sekali-kali tidak boleh orang mencari bahan-bahan penafsiran di luar undang-undang. ${ }^{31}$ Sungguhpun demikian kita tidak boleh mengabaikan kenyataan, bahwa meskipun undang-undang itu telah dibentuk dengan mempergunakan kata-kata dan istilah-istilah yang tegas, akan tetapi masih ada kemungkinan untuk memberikan berbagai penafsiran, bahkan dapat pula menimbulkan keragu-raguan. ${ }^{32}$

Untuk itu, pada contoh kasus di atas perlu dilakukan penafsiran Systematische Interpretatie, yaitu mencari hubungan antara sebagian dari sesuatu undang-undang dengan undang-undang itu sendiri. ${ }^{33} \mathrm{Hal}$ ini berfungsi untuk melihat keterkaitan Pasal 184, 185, 186, dan Pasal 263 ayat (2) KUHAP, dalam mengajukan permohonan Peninjauan Kembali. Dimana Peninjauan Kembali dapat dilakukan dengan alasan adanya novum berupa bukti baru dalam bentuk alat bukti petunjuk. Adapun mengenai alat bukti tercantum pada Pasal 184 KUHAP, yaitu: ${ }^{34}$

(1) Alat bukti yang sah ialah:

a. keterangan saksi

b. keterangan ahli

${ }^{31}$ P.A.F. Lamintang, S.H. dan C. Djisman Samosir, S.H., Delik-Delik Khusus Kejahatan Yang Ditujukan Terhadap Hak Milik Dan Lain-Lain Hak Yang Timbul Dari Hak Milik, (Bandung: TARSITO Bandung, 2010), hal. 2.

${ }^{32}$ Ibid. hal. 2.

33 P.A.F. Lamintang, S.H. dan C. Djisman Samosir, S.H., Delik-Delik Khusus Kejahatan Yang Ditujukan Terhadap Hak Milik Dan Lain-Lain Hak Yang Timbul Dari Hak Milik, (Bandung: TARSITO Bandung, 2010), hal. 4.

${ }^{34}$ Indonesia, Kitab Undang-Undang Hukum Acara Pidana, Pasal 184. 

c. surat
d. petunjuk
e. keterangan terdakwa.

(2) Hal yang secara umum sudah diketahui tidak perlu dibuktikan.

Pasal 185 KUHAP, yaitu:

(1) Keterangan saksi sebagai alat bukti ialah apa yang saksi nyatakan di sidang pengadilan.

(2) Keterangan seorang saksi saja tidak cukup untuk membuktikan bahwa terdakwa bersalah terhadap perbuatan yang didakwakan kepadanya.

(3) Ketentuan sebagaimana dimaksud dalam ayat (2) tidak berlaku apabila disertai dengan suatu alat bukti yang sah lainnya.

(4) Keterangan beberapa saksi yang berdiri sendiri-sendiri tentang suatu kejadian atau keadaan dapat digunakan sebagai suatu alat bukti yang sah apabila keterangan saksi itu ada. Hubungannya satu dengan yang lain sedemikian rupa, sehingga dapat membenarkan adanya suatu kejadian atau keadaan tertentu.

(5) Baik pendapat maupun rekaan, yang diperoleh dari hasil pemikiran saja, bukan merupakan keterangan saksi.

(6) Dalam menilai kebenaran keterangan seorang saksi, hakim harus dengan sungguh-sungguh memperhatikan
a. persesuaian antara keterangan saksi satu dengan yang lain,
b. persesuaian antara keterangan saksi dengan alat bukti lain,
c. alasan yang mungkin dipergunakan oleh saksi untuk memberi keterangan yang tertentu,
d. cara hidup dan kesusilaán saksi serta segala sesuatu yang pada umumnya dapat mempengaruhi dapat tidaknya keterangan itu dipercaya.

(7) Keterangan dari saksi yang tidak disumpah meskipun sesuai satu dengan yang lain tidak merupakan alat bukti namun apabila keterangan itu sesuai 
dengan keterangan dari saksi yang disumpah dapat dipergunakan sebagai tambahan alat bukti sah yang lain.

Pasal 186 KUHAP, yaitu:

“Keterangan ahli ialah apa yang seorang ahli nyatakan di sidang pengadilan."

Pasal 263 ayat (2) huruf a KUHAP:

“Apabila terdapat keadaan baru (novum) yang menimbulkan dugaan kuat, bahwa jika keadaan itu sudah diketahui pada waktu sidang masih berlangsung, hasilnya akan berupa putusan bebas (vrijspraak) atau putusan lepas dari segala tuntutan hukum (ontslag van alie rechtsvolging) atau tuntutan penuntut umum tidak dapat diterima (niet ontvoankelijk verklaring) atau terhadap perkara itu diterapkan ketentuan pidana yang lebih ringan."

Keterangan saksi/ahli/terdakwa yang baru muncul kemudian tidak dapat berdiri sendiri dan harus ditindaklanjuti dengan tahap pembuktian secara tersendiri atau terpisah. Hal ini berdasarkan pada kasus Sengkon dan Karta, setelah putusan berkekuatan hukum tetap menyatakan keduanya terbukti melakukan tindak pidana pembunuhan, seseorang bernama Gunel kemudian mengakui bahwa dialah pembunuh yang sebenarnya. ${ }^{35}$ Keterangan Gunel ini tidak serta merta dianggap sebagai novum, pemeriksaan dilakukan terlebih dahulu atas keterangan yang diberikan Gunel. Setelah pemeriksaan sidang pengadilan menyatakan bahwa ternyata Gunel memang bersalah melakukan tindak pidana pembunuhan yang divoniskan kepada Sengkon dan Karta, maka yang menjadi novum adalah putusan pengadilan sebagai alat bukti petunjuk.

Perkara Ahok tentunya memenuhi syarat sebagaimana Pasal 263 ayat (1) KUHAP. Peninjauan kembali diajukan terhadap putusan pemidanaan yang telah berkekuatan hukum tetap (inkracht), dan diajukan oleh terpidana. Merujuk Pasal 263 ayat (2) huruf a KUHAP, maka dapat dinyatakan telah terpenuhi syarat

\footnotetext{
35 Mahkamah Agung Republik Indonesia (b), Putusan Mahkamah Agung Nomor 6PK/Kr/1980 Tertanggal 24 Januari 1981.
} 
novum, apabila putusan Buni Yani ini telah dijatuhkan dan dinyatakan bersalah atas pelanggaran Undang-Undang Informasi dan Transaksi Elektronik. Oleh karena itu, seharusnya putusan Buni Yani ini dapat menjadi alat bukti tidak bersalahnya Ahok dalam perkara penistaan agama. Menurut Abdul Fickar Hadjar, pakar hukum pidana dari Universitas Trisakti dalam wawancara dengan team Viva, tidak ada masalah dengan peninjauan kembali yang diajukan Ahok. Sebab, peninjauan kembali itu untuk semua putusan yang berkekuatan hukum tetap dan ia juga menilai tak ada masalah jika alasan peninjauan kembali itu lantaran melihat putusan Buni Yani. Sebab, meski itu dua perkara berbeda tapi ada korelasinya. ${ }^{36}$

Penilaian terhadap keabsahan putusan pengadilan yang belum inkracht sebagai novum ini dilakukan dengan memerhatikan nilai keadilan dan kebenaran yang tidak hanya diperoleh dari aspek kepastian hukum, akan tetapi ditentukan oleh faktor keseimbangan aspek perlindungan hukum terhadap korban maupun pelaku kejahatan. Semakin serius akibat dan sifat kejahatannya maka semakin besar pula tuntutan nilai keadilan yang harus dicapai dan melebihi tuntutan nilai kepastian hukum, agar dapat mencapai nilai keadilan dan kebenaran yang lebih tinggi harus berani mereduksi nilai kepastian hukum. ${ }^{37}$ Pelaksanaan peradilan pidana mengenal istilah hukum yang dapat merangkum cita-cita peradilan pidana, istilah itu adalah due process of law atau proses hukum yang adil atau layak. Istilah ini lebih luas dari sekedar penerapan hukum atau peraturan perundangan-undangan secara formil. ${ }^{38}$

\section{Penutup}

Berdasarkan pembahasan diatas, dapat disimpulan bahwa putusan pengadilan yang belum inkracht sebagai novum dalam pengajuan peninjauan

\footnotetext{
36 "PK Ahok Dikabulkan Atau Ditolak, Ini Analisis Pakar Hukum", https://www.google.com/amp/s/m.viva.co.id/amp/berita/metro/1011102-pk-ahok-dikabulkan-atauditolak-ini-analisis-pakar-hukum, diakses pada tanggal 11 September 2019.

${ }^{37}$ Majalah Hukum Varia Peradilan November 2009 Tahun XXV No. 288, (Jakarta: IKAHI, I.S.S.N No. 0215-0247, 2009), hal. 99.

${ }^{38}$ Mardjono Reksodiputro, Bunga Rampai Permasalahan dalam Sistem Peradilan, Cetakan ke-5, (Jakarta: Pusat pelayanan dan Pengabdian Hukum Lembaga Kriminologi UI, 2007), hal. 8.
} 
kembali adalah sah. Selama prasyarat dalam Pasal 263 ayat (1) KUHAP sudah dipenuhi, maka pada ayat (2) bersifat limitative, artinya salah satu persyaratan pada ayat (2) sudah terpenuhi sehingga berdasarkan ayat (3) peninjauan kembali dapat dimohonkan kepada Mahkamah Agung. Syarat ayat (2) yang bersifat limitative ini salah satunya adalah novum berupa alat bukti petunjuk yang didapatkan setelah adanya putusan pengadilan pada perkara berbeda yang memiliki suatu korelasi. Nilai keadilan dan kebenaran didahulukan sebelum kepastian hukum, karena due process of law atau proses hukum yang adil atau layak lebih luas dari sekedar penerapan hukum atau peraturan perundanganundangan secara formil.

\section{Daftar Pustaka}

Buku

Azhary. Negara Hukum Indonesia (Analisis Yuridis Normatif tentang UnsurUnsurnya). Depok: UI Press, 1995.

Bentham, Jeremy. An Introduction to The Principles of Morals and Legislation. London: Batoche Books Kichener, 1789.

Chazawi, Adami. Lembaga Peninjauan Kembali (PK) Perkara Pidana: Penegakan Hukum dalam Penyimpangan Praktik \& Peradilan Sesat. Jakarta: Sinar Grafika, 2010.

Effendi, Tolib. Dasar-Dasar Hukum Acara Pidana: Perkembangan dan Pembaharuannya di Indonesia. Malang: Setara Press, 2014.

Kusnardi, Moh. dan Bintan Saragih. Ilmu Negara. Jakarta: Gaya Media, 2000.

Kusumaatmadja, Mochtar. Konsep-Konsep Hukum Dalam Pembangunan. Bandung: Alumni, 2006.

Lamintang, P.A.F. dan C. Djisman Samosir. Delik-Delik Khusus Kejahatan Yang Ditujukan Terhadap Hak Milik Dan Lain-Lain Hak Yang Timbul Dari Hak Milik. Bandung: TARSITO Bandung, 2010.

Marzuki, Peter Mahmud. Penelitian Hukum. (Jakarta: Kencana Prenada Media Group, 2009). 
Mulyadi, Lilik. Hukum Acara Pidana Suatu Tinjauan Khusus Terhadap Surat Dakwaan, Eksepsi dan Putusan Pengadilan. Bandung: Citra Aditya Bakti, 1996.

ND, Mukti Fajar dan Yulianto Achmad. Dualisme Penelitian Hukum Normatif dan Empiris. Cetakan Pertama. Yogyakarta: Pustaka Belajar, 2010.

Rahardjo, Satjipto. Ilmu Hukum. Bandung: Citra Aditya Bakti, 2012.

Rawls, John. A Theory of Justice, Teori Keadilan. Diterjemahkan oleh Uzair Fauzan dan Heru Prasetyo. Yogyakarta: Pustaka Pelajar, 2006.

Reksodiputro, Mardjono. Bunga Rampai Permasalahan dalam Sistem Peradilan. Cetakan Kelima. Jakarta: Pusat pelayanan dan Pengabdian Hukum Lembaga Kriminologi UI, 2007.

Rifa'I, Ahmad. Penemuan Hukum Oleh Hakim Dalam Perspektif Hukum Progresif. Jakarta: Sinar Grafika, 2011.

Sarwono. Hukum Acara Perdata Teori dan Praktik. Jakarta: Sinar Grafika, 2011.

Simanjuntak, Nikolas. Acara Pidana Indonesia dalam Sirkus Hukum. Bogor: Ghalia Indonesia, 2009.

Soekanto, Soerjono. Pengantar Penelitian Hukum. Jakarta: UI-Press, 1986.

Soekanto, Soerjono dan Purnadi Purbacaraka. Perihal Kaidah Hukum. Bandung: Alumni, 1978.

Soeparman, Parman. Pengaturan Hak Mengajukan Upaya Hukum Peninjauan Kembali dalam Perkara Pidana Bagi Korban Kejahatan. Bandung: Regika Aditama, 2009.

Sofyan, Abdi dan Abd. Asis. Hukum Acara Pidana: Suatu Pengantar. Jakarta: Kencana, 2014.

Sunggono, Bambang. Metode Penelitian Hukum. Jakarta: PT. Raja Grafindo Persada, 2007.

Bv.,Van Dale Lexicografie, Van Dale Handwoordenboek Nederlands-Engels ver. 1.0, 3rd ed., s.l: s.n, 2003.

Zaanzerberger, Georger. International Law and Order. London: Steven \& Sons Ltd., 1971. 
Jurnal

Majalah Hukum Varia Peradilan November 2009 Tahun XXV No. 288. Jakarta: IKAHI, I.S.S.N No. 0215-0247. 2009.

Zamzami, Abid. “Keadilan Di Jalan Raya”. Jurnal Yurispruden Vol. 1 No. 2. Januari 2018.

Undang-Undang:

Kitab Undang-Undang Hukum Pidana.

Undang-Undang Nomor 8 Tahun 1981 tentang Kitab Undang-Undang Hukum Acara Pidana.

Mahkamah Agung Republik Indonesia, Putusan Mahkamah Agung Nomor 109/PK/Pid/2007.

Mahkamah Agung Republik Indonesia (b), Putusan Mahkamah Agung Nomor $6 \mathrm{PK} / \mathrm{Kr} / 1980$.

Internet:

"PK Ahok Dikabulkan Atau Ditolak, Ini Analisis Pakar Hukum", https://www.google.com/amp/s/m.viva.co.id/amp/berita/metro/101110 2-pk-ahok-dikabulkan-atau-ditolak-ini-analisis-pakar-hukum, diakses pada tanggal 11 September 2019.

"Putusan Buni Yani Belum Inkrah, Dasar PK Ahok Dipertanyakan", https://m.cnnindonesia.com/nasional/20180221084125-12-277624/putusanbuni-yani-belum-inkrah-dasar-pk-ahok-dipertanyakan, diakses tanggal 24 September 2019. 